\title{
Effect of visible light on dimethylsulfoniopropionate assimilation and conversion to dimethylsulfide in the North Pacific Subtropical Gyre
}

\author{
Daniela A. del Valle ${ }^{1,2, *}$, Ronald P. Kiene ${ }^{3}$, David M. Karl ${ }^{1,2}$ \\ ${ }^{1}$ Department of Oceanography, University of Hawaii, Honolulu, Hawaii 96822, USA \\ ${ }^{2}$ Center for Microbial Oceanography: Research and Education (C-MORE), 1950 East-West Road, Honolulu, Hawaii 96822, USA \\ ${ }^{3}$ Department of Marine Sciences, University of South Alabama, Mobile, Alabama 36688, USA
}

\begin{abstract}
The aim of the present study was to assess the effect of photosynthetically active radiation (PAR, 400 to $700 \mathrm{~nm}$ ) on the utilization of dissolved dimethylsulfoniopropionate (DMSPd) by microbial communities in the oligotrophic North Pacific Subtropical Gyre, using ${ }^{35}$ S-labeled substrate. Rates of DMSPd-sulfur (DMSPd-S) assimilation into macromolecules of microorganisms in surface mixed layer seawater were 39 to $78 \%$ higher in samples that were incubated in the light than in dark controls. There was no photoinhibition in the light range tested (up to $1200 \mu \mathrm{mol}$ photons $\mathrm{m}^{-2} \mathrm{~s}^{-1}$ ). Leucine assimilation, an index of bacterial protein production, was also photostimulated and was significantly correlated $(r=0.93)$ to DMSPd-S assimilation, suggesting that cells can respond to an increase in $\mathrm{S}$ requirements for protein synthesis by assimilating DMSPd-S. Lightdriven changes in DMSPd-S assimilation were inversely and significantly correlated $(r=-0.57)$ to changes in the corresponding dimethylsulfide (DMS) yield (i.e. DMS produced per DMSP consumed), in support of the hypothesis that DMS is produced only after cellular sulfur requirements are met. While light-driven changes in DMSPd-S assimilation appear to affect DMS yield, more than half of the DMSPd product pool remained unidentified; thus, in addition to assimilation, there may be other metabolic processes or products that can regulate DMS production.
\end{abstract}

KEY WORDS: Dimethylsulfoniopropionate $\cdot$ Dimethylsulfide $\cdot$ Assimilation $\cdot$ Leucine $\cdot$ Light ALOHA

Resale or republication not permitted without written consent of the publisher

\section{INTRODUCTION}

The algal osmolyte dimethylsulfoniopropionate (DMSP) is a reduced sulfur compound that is present globally in the oceanic euphotic zone. DMSP is produced by a wide variety of marine phytoplankton (e.g. dinoflagellates, prymnesiophytes, and diatoms; Keller et al. 1989), and in certain habitats, up to $10 \%$ of the carbon fixed in the surface ocean can be allocated to the production of DMSP (Simó et al. 2002). Intracellular DMSP can be released into seawater following senescence, algal death, viral lysis, grazing, and exudation. Once released, it becomes a potentially important source of reduced carbon (C) and sulfur (S) for microbial metabolism (Kiene et al. 1999, Malmstrom et al. 2004, Vila et al. 2004). Interest in DMSP cycling also comes from the fact that it is the precursor of the climatically active trace gas dimethylsulfide (DMS), which may influence the Earth's climate system by increasing albedo through the formation of aerosol particles that scatter sunlight and affect cloud condensation nuclei formation in the marine atmosphere (Shaw 1983, Charlson et al. 1987).

Microbes can catabolize DMSP through 2 different pathways. The first is the demethylation/demethiolation (d/d) pathway, in which DMSP-sulfur (DMSP-S) can be incorporated into amino acids and proteins, with methanethiol as a key intermediary (Kiene et al. 
1999). The second DMSP degradation pathway is via conversion into DMS, either through the direct action of lyases (Steinke et al. 1996) or an alternate pathway involving the addition of acyl coenzyme A to DMSP (Todd et al. 2007). Normally, DMS does not constitute more than $15 \%$ of the product pool from extracellular dissolved DMSP (DMSPd) (Kiene \& Linn 2000b), with most of the DMSPd following the $d / d$ pathway. The factors controlling the preference of one metabolic pathway over the other are not clear. At the cellular level, it has been suggested that DMS is produced once the cellular requirements for $\mathrm{S}$ have been met, either from assimilatory sulfate reduction, DMSP metabolism, or from other reduced-S compounds present in the environment (Kiene et al. 2000, Pinhassi et al. 2005). At the community level, several additional factors may be responsible for the variable DMS yields, including microbial composition, nutrient status, and light conditions, among others. A comprehensive understanding of the controls of the different microbial DMSP degradation pathways is important because microbial production of DMS will determine the potential flux to the atmosphere. Few studies have concomitantly measured the production of DMS and the assimilation of DMSP-S into proteins (Kiene et al. 1999, Slezak et al. 2007, Lizotte et al. 2009, Royer et al. 2010), and only 1 study has attempted to identify a relationship between the 2 processes. Lizotte et al. (2009) reported an inverse correlation between DMS and assimilation yields during the evolution of a Fe-induced phytoplankton bloom, but this change in DMSP metabolism could have been due to changes in the composition of the microbial assemblage, physiological regulation, or a change in the bioavailability of labile sulfur compounds during the development of the bloom.

Photoheterotrophy appears to be a common and important trait in the oceans and a key strategy especially in oligotrophic systems, where light penetrates deep in the water column (Zubkov 2009). Numerous studies have shown light-stimulated assimilation of different amino acids in mixed assemblages (Church et al. 2004, Church et al. 2006, Michelou et al. 2007, Mary et al. 2008), highlighting the importance of light-driven heterotrophic production and dissolved organic matter assimilation in oceanic systems. Usually, the study of the processes involved in the cycling of DMSP are carried out in dark incubations, even though assimilation of DMSP-S and DMS production have been shown to be affected, both positively and negatively, by light at a community level (Slezak et al. 2007). The assimilation of reduced S from DMSP by Prochlorococcus, Synechococcus, and picoeukaryotes has been shown to be light-stimulated (Vila-
Costa et al. 2006, Ruiz-González et al. 2012), but the conditions under which this occurs and the relationship to general heterotrophic activity have not been investigated to date.

In this work, we evaluated the effect of photosynthetically active radiation (PAR) on DMSPd-S assimilation using ${ }^{35} \mathrm{~S}$-radiolabeled substrate, and assessed whether DMSPd-S assimilation is correlated to leucine assimilation for protein biosynthesis in the microbial community of the North Pacific Subtropical Gyre (NPSG). We further analyzed the effect of PAR on DMS production and evaluated the hypothesis that the $d / d$ and the DMS production pathway are competing mechanisms.

\section{MATERIALS AND METHODS}

\section{Study site}

Seawater samples were collected in the summer (August 20 to 29, cruise KM1016; Stns 3, 4, and 5) and fall (October 2 to 6, cruise HOT226; Stn ALOHA) of 2010 near the Hawaii Ocean Time-series (HOT) Stn ALOHA $\left(22^{\circ} 45^{\prime} \mathrm{N}, 158^{\circ} 00^{\prime} \mathrm{W}\right.$; Karl \& Lukas 1996), aboard the RV 'Kilo Moana' (Fig. 1). Detailed information about Stn ALOHA (physical and biogeochemical parameters) can be found on the Hawaii Ocean

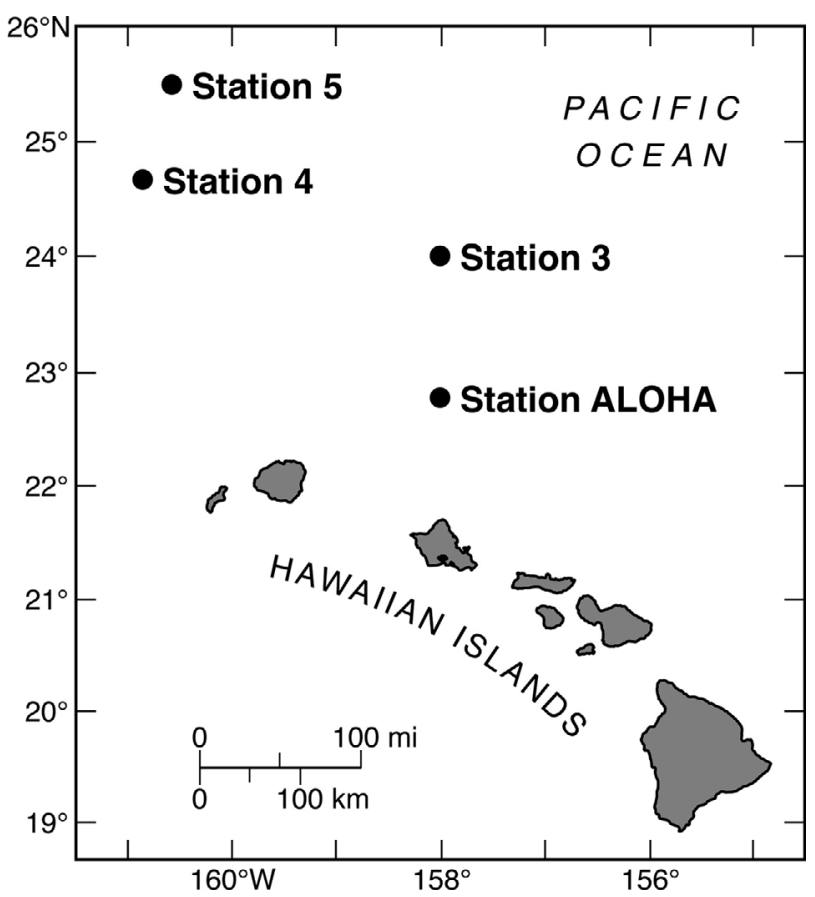

Fig. 1. Location of sampled stations during cruises on August 20 to 29, 2010 (Stns 3, 4, and 5) and on October 2 to 6, 2010 (Stn ALOHA) 
Time-series Data Organization \& Graphical System (HOT-DOGS, http://hahana.soest.hawaii.edu/hot/hotdogs/).

\section{Sampling}

All of the seawater samples were collected during the night or early dawn (02:00 to 07:00 h) using $12 \mathrm{l}$ polyvinylchloride (PVC) sample bottles attached to a conductivity, temperature, and depth (CTD) rosette. Seawater was sampled from a PVC bottle into acidrinsed, dark polycarbonate bottles or borosilicate vials covered with aluminum foil and transported to the radioisotope mobile laboratory for further processing.

\section{Depth profiles}

One depth profile was carried out at each station sampled (see Fig. 1 for locations) to characterize the depth distributions of DMSP pools and the microbial turnover rate of DMSPd in the upper water column (5 to $125 \mathrm{~m}$ ). Measurements included concentrations of total DMSP (sum of particle-associated plus extracellular), DMSPd, and the rate constant ( $k$, in units of $\mathrm{h}^{-1}$ ) of DMSPd turnover.

\section{Effect of natural PAR on DMSPd-S assimilation}

The effect of PAR on DMSPd-S assimilation was studied by incubating paired light and dark bottle samples in an on-deck incubator with circulating surface seawater. Seawater from discrete depths was collected at 07:00 $\mathrm{h}$ and amended with both ${ }^{35} \mathrm{~S}$ DMSPd and ${ }^{3} \mathrm{H}$-leucine (see 'DMSPd-S and leucine assimilation' below). To test the effect of a single PAR dose (40\% of surface) on ${ }^{35} \mathrm{~S}$-DMSPd and ${ }^{3} \mathrm{H}$-leucine assimilation on samples from different depths throughout the water column, subsamples from each depth were transferred to triplicate $25 \mathrm{ml}$ borosilicate glass vials, which were placed either in a dark bag (dark treatment) or without a bag (light treatment) in the deckboard incubator. The incubator was built of blue acrylic to match the underwater spectrum, attenuate the surface incident PAR radiation by $40 \%$ and remove $\sim 100 \%$ of the ultraviolet (UV) radiation. Samples were incubated on deck from 07:30 to 11:30 h, local time. The average light doses experienced during the experiments carried out at Stns 3, 4, 5, and ALOHA were 5.2, 5.4, 5.3, and $5.4 \mathrm{~mol}$ photons $\mathrm{m}^{-2}$, respectively.

\section{Response of ${ }^{35} \mathrm{~S}-\mathrm{DMSPd}$ assimilation to irradiance}

A photosynthetron incubator (Lewis \& Smith 1983) was utilized to examine the response of ${ }^{35} \mathrm{~S}-\mathrm{DMSPd}$ and ${ }^{3} \mathrm{H}$-leucine incorporation into proteins at different irradiance levels, ranging from 0 to $1200 \mu \mathrm{mol}$ photons $\mathrm{m}^{-2} \mathrm{~s}^{-1}$. The average surface PAR irradiance at noon was 1460 and $1430 \mu \mathrm{mol}$ photons $\mathrm{m}^{-2} \mathrm{~s}^{-1}$ during the cruises KM1016 and HOT226, respectively. A seawater sample was first transferred from the collection device into a $500 \mathrm{ml}$ dark polycarbonate bottle and spiked with tracer amounts (2.6 to $10.7 \mathrm{pM}$ ) of ${ }^{35} \mathrm{~S}-\mathrm{DMSPd}$ (specific activity: 6.3 to $12.6 \mathrm{kBq} \mathrm{pmol}^{-1}$ ). After gentle mixing, two $0.5 \mathrm{ml}$ subsamples were pipetted into $6 \mathrm{ml}$ glass scintillation vials containing $4.5 \mathrm{ml}$ of Ultima-Gold scintillation cocktail for measurement of the total activity added $(\sim 33.3$ to 66.6 $\mathrm{Bq} \mathrm{ml}{ }^{-1}$ ). Immediately afterwards, ${ }^{3} \mathrm{H}$-leucine (specific activity: 57.0 to $66.6 \mathrm{kBq} \mathrm{nmol}^{-1}$ ) was added to a final concentration of $20 \mathrm{nM}$, and two $0.5 \mathrm{ml} \mathrm{sub-}$ samples were pipetted into scintillation cocktail to verify the activity of leucine added. The dual-label amended sample was divided into a series of $20 \mathrm{ml}$ borosilicate glass scintillation vials (11 to 22, depending on the experiment), which were closed with PTFE/silicone septa and a phenolic screw cap. The vials were placed in individual wells (each receiving a known photon flux) in a cooling block connected to a water bath to maintain the samples at in situ temperature $\left( \pm 0.5^{\circ} \mathrm{C}\right)$, and the light source $(1500 \mathrm{~W}$ halogen bulb with blue filter) was turned on. After $2 \mathrm{~h}$, the samples were removed from the light-exposure incubator and immediately subsampled for analytical measurements (see below). At one location (Stn 4), the recovery capability of light-exposed seawater samples from $25 \mathrm{~m}$ and $125 \mathrm{~m}$ depth was tested by incubating vials amended with ${ }^{35} \mathrm{~S}$-DMSP for $2 \mathrm{~h}$ in the light and then placing them in the dark for another $2 \mathrm{~h}$ (post-light treatment), subsampling both before and after the dark incubation.

The relation between DMSPd-S assimilation and DMS yield from ${ }^{35} \mathrm{~S}-\mathrm{DMSPd}$ consumption was also studied under different light levels using the photosynthetron, using water collected from $25 \mathrm{~m}$ at Stn 3 and Stn ALOHA. In these experiments, the sample was first amended with $200 \mathrm{nM}$ dimethyldisulfide (DMDS) to inhibit consumption of the ${ }^{35}$ S-DMS produced during the incubation (Wolfe \& Kiene 1993) and then spiked with ${ }^{35} \mathrm{~S}-\mathrm{DMSPd}$. The sample was divided into $20 \mathrm{ml}$ borosilicate glass vials, minimizing the amount of headspace $(<2.5 \% \mathrm{v} / \mathrm{v})$. The samples were incubated for $2 \mathrm{~h}$ in the photosynthetron before being processed as described below. 


\section{Fate of consumed ${ }^{35} \mathrm{~S}-\mathrm{DMSP}$}

Seawater collected from $25 \mathrm{~m}$ at Stn 4 was amended with ${ }^{35} \mathrm{~S}$-DMSP and transferred into a series of $40 \mathrm{ml}$ borosilicate glass serum vials. The vials were incubated in the dark at the surface temperature, and triplicate vials were sacrificed at different time points to track the fate of the label into the following pools: ${ }^{35}$ S-total uptake, ${ }^{35} \mathrm{~S}$-assimilation, ${ }^{35} \mathrm{~S}-\mathrm{DMS}$, ${ }^{35} \mathrm{~S}$-volatiles, and ${ }^{35} \mathrm{~S}$-dissolved non-volatiles (see below for methodological details).

\section{DMSP concentrations}

Samples for total DMSP (DMSPt) determination were collected directly from the rosette-mounted PVC bottle by transferring $10 \mathrm{ml}$ of seawater into $15 \mathrm{ml}$ centrifuge tubes containing $50 \mu \mathrm{l}$ of $50 \% \mathrm{H}_{2} \mathrm{SO}_{4}$. The use of $\mathrm{H}_{2} \mathrm{SO}_{4}$ stops biological activity and also oxidizes any DMS present in the sample, preventing it from interfering with the indirect DMSP determination described below. Samples for DMSPd were obtained following the small volume drip filtration (SVDF) method, as described by Kiene \& Slezak (2006). Briefly, $100 \mathrm{ml}$ of seawater sample were transferred into a polysulfone filtration tower holding a $47 \mathrm{~mm}$ glass fiber (GF/F) filter and gravity filtered. Only the first $3.5 \mathrm{ml}$ of the filtered sample were collected in a $15 \mathrm{ml}$ centrifuge tube containing $50 \mu \mathrm{l}$ of $50 \% \mathrm{H}_{2} \mathrm{SO}_{4}$ and stored for further analysis. For DMSPt and DMSPd analysis, $1 \mathrm{ml}$ and $3.2 \mathrm{ml}$ subsamples were pipetted into glass vials, respectively. To cleave the DMSP into DMS, $1 \mathrm{ml}$ of $5 \mathrm{M} \mathrm{NaOH}$ was added to the subsample, and the vial was rapidly closed with a Teflon-faced butyl stopper and crimp-sealed. The produced DMS was sparged, cryotrapped, and then injected into a Shimadzu GC-14A gas chromatograph equipped with a S-selective flame photometric detector for quantification (Kiene \& Service 1991).

\section{Consumed ${ }^{35}$ S-DMSPd}

The fraction of consumed ${ }^{35} \mathrm{~S}$-DMSPd was defined as the net loss of ${ }^{35} \mathrm{~S}$-DMSPd from the dissolved pool. To quantify this fraction, subsamples were pipetted into a 10-place Hoefer filtration manifold set up with $0.2 \mu \mathrm{m}$ nylon filters, and a gentle vacuum was applied $(<5 \mathrm{~mm} \mathrm{Hg})$. The filtrate was collected in a $6 \mathrm{ml}$ glass scintillation vial containing $50 \mu \mathrm{l}$ of $50 \% \mathrm{H}_{2} \mathrm{SO}_{4}$ and stored for $>24 \mathrm{~h}$ for further processing. The filtration was stopped before the filter went dry to minimize cell rupture and release of ${ }^{35} \mathrm{~S}$-DMSPd from cells. To determine the fraction left as ${ }^{35} \mathrm{~S}$-DMSPd in the filtrate (i.e. the dissolved fraction), a 1 to $3 \mathrm{ml}$ subsample of filtrate was transferred to a $40 \mathrm{ml}$ serum vial, which was sealed with a rubber stopper fitted with a plastic cup. The plastic cup held a $25 \mathrm{~mm} \mathrm{GF/F} \mathrm{filter} \mathrm{soaked}$ with $200 \mu \mathrm{l}$ of $3 \% \mathrm{H}_{2} \mathrm{O}_{2}$. To cleave the DMSP into DMS that could be trapped on the filter, $250 \mu \mathrm{l}$ of $5 \mathrm{M}$ $\mathrm{NaOH}$ was injected through the stopper. The ${ }^{35} \mathrm{~S}-\mathrm{DM}$ SPd consumed was calculated as the difference between the total added label and the amount of ${ }^{35} \mathrm{~S}$ DMSPd remaining in the dissolved fraction. To obtain DMSPd consumption rates, samples amended with ${ }^{35} \mathrm{~S}$-DMSPd were incubated in the dark at surface temperature, and subsamples were taken at 30,60, and $90 \mathrm{~min}$ and processed as described above. The consumption rate constant was calculated as the slope of the natural log of the fraction of ${ }^{35} \mathrm{~S}$-DMSPd remaining versus time, and the consumption rate was calculated by multiplying the rate constant by the corresponding DMSPd concentration at the start of the experiment. The amount of label present as dissolved non-volatile products from DMSP consumption was also quantified by pipetting $1 \mathrm{ml}$ of the degassed filtrate into scintillation cocktail, and this number was corrected by the amount of ${ }^{35} \mathrm{~S}-\mathrm{DMSP}$ that remained untransformed.

\section{DMSPd-S and leucine assimilation}

For assimilation into proteins, after incubating the samples with amended ${ }^{35} \mathrm{~S}$-DMSP and ${ }^{3} \mathrm{H}$-leucine, a known volume of sample (5 to $10 \mathrm{ml}$ ) was filtered $(0.2 \mu \mathrm{m})$ using a gentle vacuum $(<5 \mathrm{~mm} \mathrm{Hg})$. The filtration was interrupted when there was $\sim 1 \mathrm{ml}$ of sample left above the filter, and $4 \mathrm{ml}$ of $5 \%$ trichloroacetic acid (TCA) at $4{ }^{\circ} \mathrm{C}$ was added onto the filter. After $10 \mathrm{~min}$, filtration was resumed, and the filter was rinsed 4 times with $1 \mathrm{ml}$ of MilliQ water. The radioactivity on the filter was determined by liquid scintillation counting, providing a quantification of the label assimilated into the macromolecular TCA-insoluble fraction. Samples were counted using a dual isotope assay for ${ }^{3} \mathrm{H}$ and ${ }^{35} \mathrm{~S}$ in a Perkin Elmer liquid scintillation counter. The specific activity of the leucine stock was adjusted based on preliminary tests of the signalto-background ratio for various activity concentrations of ${ }^{35} \mathrm{~S}$ and ${ }^{3} \mathrm{H}$, to avoid cross-contamination of the ${ }^{3} \mathrm{H}$ signal into the ${ }^{35} \mathrm{~S}$ signal. To determine incubation times and to test for a potential interaction due to the use of dual labeling, time courses of assimilation were carried out with seawater from $25 \mathrm{~m}$ depth at Stn 
ALOHA and Stn 3. The samples were collected from the rosette-mounted PVC bottle into acid-washed 41 polycarbonate bottles and divided into $240 \mathrm{ml}$ serum vials, which were subsequently amended with either ${ }^{3} \mathrm{H}$-leucine, ${ }^{35} \mathrm{~S}$-DMSPd or both; each treatment was conducted in triplicate. At discrete time points $(1,2,3$, $4,5,9$, and $12 \mathrm{~h})$, subsamples were taken to determine the assimilated fraction of each isotopically labeled substrate. Based on the results from these time courses (data not shown), subsequent incubations were kept to less than $4 \mathrm{~h}$, to ensure linear uptake of both labeled compounds. The addition of either substrate had no significant effect on the assimilation of the other labeled substrate (repeated measures ANOVA, p < 0.05), and therefore dual label incubations were performed when necessary.

\section{${ }^{35} \mathrm{~S}-\mathrm{DMS}$ and ${ }^{35} \mathrm{~S}-\mathrm{volatile}$ production}

When the aim of the experiment was to measure gross production of ${ }^{35} \mathrm{~S}-\mathrm{DMS}$ from ${ }^{35} \mathrm{~S}$-DMSP, DMDS (200 nM final concentration) was added prior to the addition of ${ }^{35} \mathrm{~S}-\mathrm{DMSPd}$ to ensure inhibition of DMS uptake (Wolfe \& Kiene 1993). In contrast, when we were interested in net ${ }^{35} \mathrm{~S}-\mathrm{DMS}$ production, no inhibitor was added. For ${ }^{35} \mathrm{~S}-\mathrm{DMS}$ production determination, at the end of the incubation, a 2 to $5 \mathrm{ml} \mathrm{sub-}$ sample was transferred into a $40 \mathrm{ml}$ glass vial containing $100 \mu \mathrm{l}$ of $10 \%$ sodium dodecylsulfate (SDS), $100 \mu \mathrm{l}$ of $200 \mathrm{mM}$ unlabeled DMSPd to stop further ${ }^{35} \mathrm{~S}-\mathrm{DMSPd}$ transformation, and $0.05 \mathrm{ml}$ of Ellman's reagent (1 mg 5,5-dithiobis[2-nitrobenzoic] acid per $\mathrm{ml}$ of $50 \mathrm{mM}$ Trizma-HCl, $\mathrm{pH}$ 8). Ellman's reagent is normally used to complex thiols, including methanethiol (Ellman 1958), but it does not complex DMS. The vial was closed with a rubber stopper and plastic cup holding a $3 \% \quad \mathrm{H}_{2} \mathrm{O}_{2}$-soaked filter as described in the section 'Consumed ${ }^{35} \mathrm{~S}$-DMSPd'. After $24 \mathrm{~h}$, the radioactivity in the filter was determined by liquid scintillation counting. The same procedure was repeated for total ${ }^{35} \mathrm{~S}$-volatiles, but for these samples no Ellman's reagent was added.

\section{Total uptake and retention of untransformed ${ }^{35} \mathrm{~S}-\mathrm{DMSP}$}

The total amount of ${ }^{35} \mathrm{~S}$-label taken up into the cell was quantified by filtering the sample at the end of the incubation onto $0.2 \mu \mathrm{m}$ nylon filters with a procedure similar to that used for the assimilation of DMSP-S into protein. In this case, four $1 \mathrm{ml}$ rinses with
$0.2 \mu \mathrm{m}$-filtered seawater were performed to remove dissolved label. The activity on the filter (total uptake) was quantified by liquid scintillation counting. To determine the fraction of the cell-associated label still present as ${ }^{35} \mathrm{~S}-\mathrm{DMSPd}$, a parallel sample was filtered and rinsed following the same procedures as for the total uptake, but the filter was transferred to a $40 \mathrm{ml}$ serum vial containing $2 \mathrm{ml}$ of $0.2 \mu \mathrm{m}$-filtered seawater. The vial was closed with a rubber stopper holding a cup with a $3 \% \mathrm{H}_{2} \mathrm{O}_{2}$-soaked filter, and $250 \mu \mathrm{l}$ of $5 \mathrm{M}$ $\mathrm{NaOH}$ were injected through the stopper to transform ${ }^{35} \mathrm{~S}-\mathrm{DMSP}$ into ${ }^{35} \mathrm{~S}-\mathrm{DMS}$, as described in the section 'Consumed ${ }^{35} \mathrm{~S}-\mathrm{DMSPd}$ '. The ${ }^{35} \mathrm{~S}-\mathrm{DMS}$ was oxidized to ${ }^{35} \mathrm{~S}$-DMSO, trapped on the $\mathrm{H}_{2} \mathrm{O}_{2}$-soaked wick and subsequently counted by liquid scintillation counting (Kiene \& Linn 2000b).

\section{Flow cytometry analysis}

Samples for flow cytometry analysis were fixed with $0.24 \%$ (final concentration) paraformaldehyde and frozen immediately in liquid nitrogen. Abundances of Prochlorococcus, Synechococcus, picophytoeukaryotes, and heterotrophic bacteria were determined as described by Marie et al. (1997) using a Cytopeia Influx flow cytometer.

\section{Data analysis}

The response of both ${ }^{35} \mathrm{~S}$-DMSPd and ${ }^{3} \mathrm{H}$-leucine assimilation rates to irradiance was fitted by leastsquares regression to a model slightly adapted from the Platt et al. (1980) curve for photosynthesis versus irradiance (Eq. 1). The adapted model incorporated a term for the dark assimilation rate $\left(A_{d}\right)$, as reported by Church et al. (2004):

$$
A=A_{\mathrm{S}}\left[1-\exp ^{\left(-\alpha E / A_{\mathrm{S}}\right)}\right]\left[\exp ^{\left(-\beta E / A_{\mathrm{S}}\right)}\right]+A_{\mathrm{d}}
$$

where $A$ is the predicted assimilation rate, $A_{\mathrm{s}}$ is the maximum assimilation rate minus $A_{d}$, in the absence of photoinhibition, $\alpha$ is the initial slope of the response of assimilation rate at experimental irradiances $(E)$ close to zero, and $\beta$ is the initial slope of the

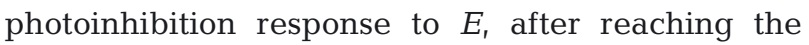
maximum assimilation rate. From the fitted parameters, the maximum assimilation rate in the presence of photoinhibition $\left(A_{\mathrm{m}}\right.$, Eq. 2$)$ and the light intensity at which this rate is attained ( $E_{k}$, Eq. 3) were calculated as follows:

$$
\begin{gathered}
A_{\mathrm{m}}=A_{\mathrm{S}}\left(\frac{\alpha}{\alpha+\beta}\right)\left(\frac{\beta}{\alpha+\beta}\right)^{\beta / \alpha}+A_{\mathrm{d}} \\
E_{k}=A_{\mathrm{m}} / \alpha
\end{gathered}
$$




\section{RESULTS}

\section{Water column characteristics}

To characterize the environment, several water column properties were measured in the 5 to $125 \mathrm{~m}$ depth horizon (Fig. 2, Table 1). Mixed layer depths were within the range typically encountered during the summer months at Stn ALOHA, ranging from 34 to
$58 \mathrm{~m}$. Average surface mixed layer (SML) DMSPt and DMSPd concentrations ranged from 10.0 to $14.4 \mathrm{nM}$ and 0.50 to $0.99 \mathrm{nM}$, respectively, and these concentrations decreased with depth, reaching their lowest measured levels at $125 \mathrm{~m}$ (Fig. 2). DMSPd constituted a smaller fraction of the DMSPt pool in the SML (5.0 to $7.3 \%$ ) than below it ( 8.6 to $10.5 \%$ ). DMSPd consumption rate constants $(k)$ in the upper $125 \mathrm{~m}$ of the water column ranged from 0.08 to $0.28 \mathrm{~h}^{-1}$, yielding turnover times for DMSPd of 3.6 to $12.1 \mathrm{~h}$. Rate constants were not significantly different at different depths in the top $100 \mathrm{~m}$ but were lower at $125 \mathrm{~m}$. DMSPd consumption rates $(k \times$ [DMSPd] $)$ decreased with depth, driven by the simultaneous decreases in both $k$ and DMSPd concentrations, and ranged from 0.4 to $6.5 \mathrm{nM} \mathrm{d}^{-1}$.

\section{Effect of PAR on DMSPd-S assimilation}

Samples collected from different depths at Stns 3, 4, 5, and ALOHA were exposed to one level of PAR irradiance $(40 \%$ of solar PAR; equivalent to that at $\sim 21 \mathrm{~m}$ ) for comparison to samples incubated in the dark. Seawater samples collected from 5 to $55 \mathrm{~m}$ presented higher leucine and DMSPd$\mathrm{S}$ assimilation rates in the light than in the dark (Fig. 3). In contrast, samples collected from deeper depths showed either no difference between dark and light assimilation rates $(75 \mathrm{~m})$, or higher DMSP and leucine assimilation rates in the dark $(125 \mathrm{~m})$ than in the light. To understand the observed pattern, we investigated the effect of PAR intensity on DMSPd-S assimilation.

\section{Response of DMSPd-S assimilation to variable irradiance}

Photosynthetron experiments were conducted using water collected from the surface mixed layer (SML, $25 \mathrm{~m}$ ) and from below the SML but within the photic zone (BSML, $125 \mathrm{~m}$ ). In these experiments, assimilation of DMSPd-S in both SML and BSML samples was
Fig. 2. Vertical profiles of (A) dissolved dimethylsulfoniopropionate (DMSPd) concentrations, (B) total DSMP (DMSPt) concentrations, (C) DMSPd consumption rate constant $(k)$, and (D) DMSPd consumption rates at different stations during late summer and early fall of 2010. DMSPd and DMSPt concentrations were not collected at Stn 5. Error bars indicate SD 
Table 1. Summary of water column properties at the studied stations, including dimethylsulfoniopropionate (DMSP) concentrations in the total (DMSPt) and dissolved (DMSPd) fractions. PAR: photosynthetically active radiation; bact.: bacteria; picoeuk.: picoeukaryotes; NA: not available

\begin{tabular}{|c|c|c|c|c|c|c|c|c|c|c|c|c|}
\hline Depth & Stn & $\begin{array}{c}\mathrm{MLD}^{\mathrm{a}} \\
(\mathrm{m})\end{array}$ & $\begin{array}{c}1 \% \text { PAR } \\
(\mathrm{m})\end{array}$ & $\begin{array}{c}\text { DMSPt } \\
\text { (nM) }\end{array}$ & $\begin{array}{l}\text { DMSPd } \\
(\mathrm{nM})\end{array}$ & $\begin{array}{c}\text { Heterotrophic } \\
\text { bact. }\left(10^{5}\right. \\
\left.\text { cells } \mathrm{ml}^{-1}\right)\end{array}$ & $\begin{array}{c}\text { Prochloro- } \\
\text { coccus } \\
\left(10^{5} \text { cells ml }{ }^{-1}\right)\end{array}$ & $\begin{array}{c}\text { Synecho- } \\
\text { coccus } \\
\left(\text { cells ml }{ }^{-1}\right)\end{array}$ & $\begin{array}{l}\text { Picoeuk. } \\
\left(\text { cells ml }{ }^{-1} \text { ) }\right.\end{array}$ & $\begin{array}{c}\text { DMSP } \\
\text { turnover } \\
(\mathrm{h})\end{array}$ & $\begin{array}{c}\text { DMSPd } \\
\text { consumption } \\
\text { rate }\left(\mathrm{pM} \mathrm{h}^{-1}\right)\end{array}$ & $\begin{array}{c}\text { Leucine } \\
\text { assimilation } \\
\text { rate }\left(\mathrm{pM} \mathrm{h}^{-1}\right)\end{array}$ \\
\hline \multirow[t]{4}{*}{$\mathrm{SML}^{\mathrm{b}}$} & 3 & 55 & 101 & 10.0 & 0.50 & 5.51 & 1.86 & 1400 & 945 & 7.4 & 84.5 & 11.6 \\
\hline & 4 & 34 & 101 & 14.4 & 0.76 & 5.18 & 1.71 & 561 & 1075 & 4.1 & 235.0 & 21.0 \\
\hline & 5 & 34 & 112 & NA & NA & NA & NA & NA & NA & 4.5 & NA & 16.7 \\
\hline & ALOHA & 58 & 95 & 13.5 & 0.99 & NA & 2.93 & 1303 & 953 & 4.5 & 285.0 & 17.5 \\
\hline \multirow[t]{4}{*}{$125 \mathrm{~m}$} & 3 & 55 & 101 & 2.2 & 0.19 & 2.82 & 0.33 & 12 & 1082 & 12.1 & 19.6 & 6.1 \\
\hline & 4 & 34 & 101 & 3.6 & 0.33 & 3.75 & 0.18 & 1535 & 1007 & 7.6 & 55.8 & 6.1 \\
\hline & 5 & 34 & 112 & NA & NA & NA & NA & NA & NA & 10.6 & NA & 7.2 \\
\hline & ALOHA & 58 & 95 & 4.3 & 0.45 & NA & 0.61 & 141 & 1429 & 8.5 & 67.5 & 10.2 \\
\hline
\end{tabular}

Light/dark assimilation rate
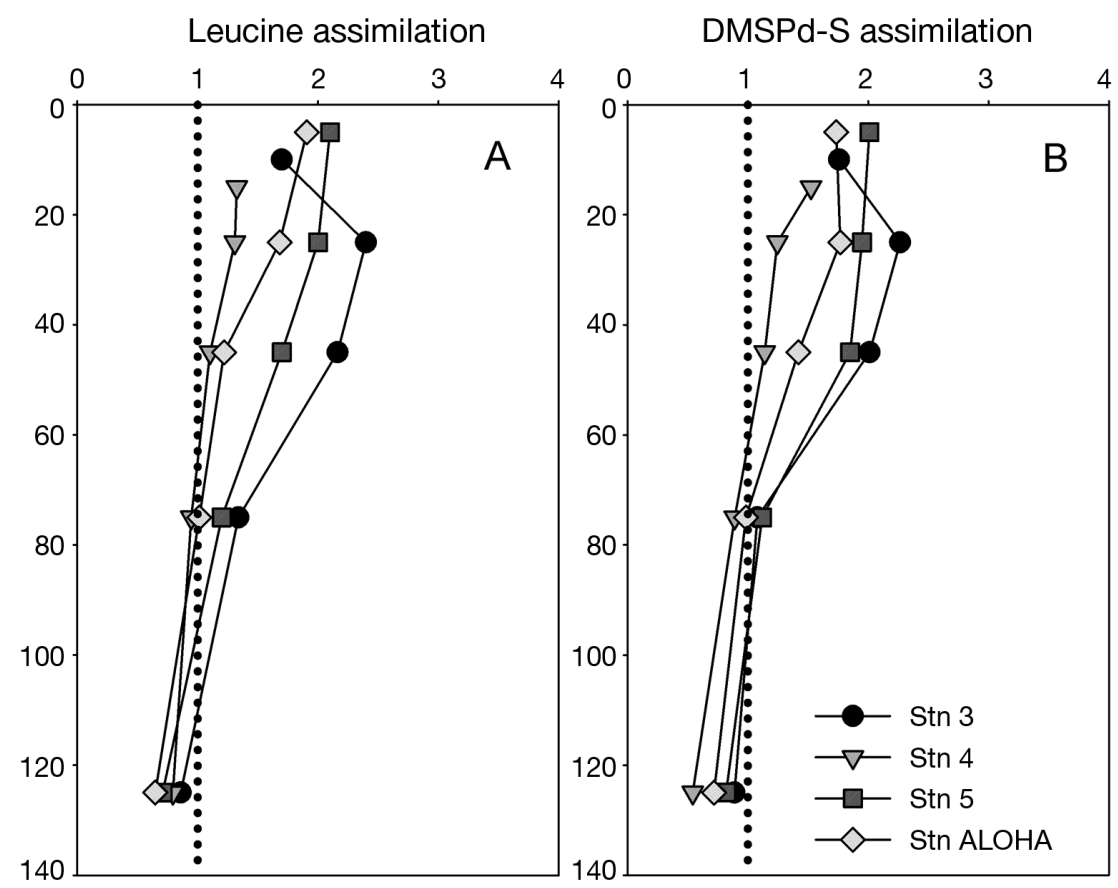

Fig. 3. Ratio of light- versus dark-incubated (A) leucine and (B) DMSPd-S assimilation rates (DMSPd: dissolved dimethylsulfoniopropionate) Samples were collected at a given depth and incubated on deck under either a light or dark treatment. The light intensity experienced by all light incubated samples was equivalent to the irradiance reaching $\sim 21 \mathrm{~m}$ depth $(40 \%$ surface PAR); therefore, samples collected at 5, 25, 45, 75, and $125 \mathrm{~m}$ received 0.5, 1.1, 2.4, 8.2 , and 63 times the flux that they would have received if incubated in situ at the collection depth, respectively. Dotted line indicates the 1:1 ratio

stimulated by light exposure (Fig. 4). For SML seawater, DMSPd-S assimilation increased with irradiance, reaching maximum rates at 43 to $92 \mu \mathrm{mol}$ photons $\mathrm{m}^{-2} \mathrm{~s}^{-1}$ (Table 2), which were 26 to $48 \%$ higher than the rates in dark incubated samples. SML samples did not show significant photoinhibition within the light intensity range tested (up to $1200 \mu \mathrm{mol}$ photons $\mathrm{m}^{-2} \mathrm{~s}^{-1}$; Fig. 4). For SML seawater, the adapted Platt et al. (1980) model of the photosynthesis-irradiance relationship fitted the observed data and explained 71 to $81 \%$ of the variance.

BSML samples presented a different response to irradiance than the SML samples. In BSML samples, the DMSPd-S assimilation maxima were observed at lower PAR irradiances, ranging from 15 to $34 \mu \mathrm{mol}$ photons $\mathrm{m}^{-2} \mathrm{~s}^{-1}$, and the maximal assimilation rates were 37 to $60 \%$ higher than the dark incubated values. At higher light intensities, DMSPd-S assimilation was photoinhibited in the BSML samples, with assimilation rates 30 to $43 \%$ lower than the maxima and even reaching lower rates than in the dark incubations. The adapted Platt et al. (1980) model does not mathematically allow values lower than the dark assimilation; therefore, values lower and up to $5 \%$ higher than the dark assimilation rate were removed from the regression analysis. Exclusion of those low values did not affect the estimation of the photophysiological parameters obtained from the model and, using the truncated data sets, the fitted model explained 60 to $80 \%$ of the variance.

Leucine assimilation also followed the adapted Platt et al. (1980) model $\left(\mathrm{R}^{2}=0.49\right.$ to 0.94 , Table 2, 

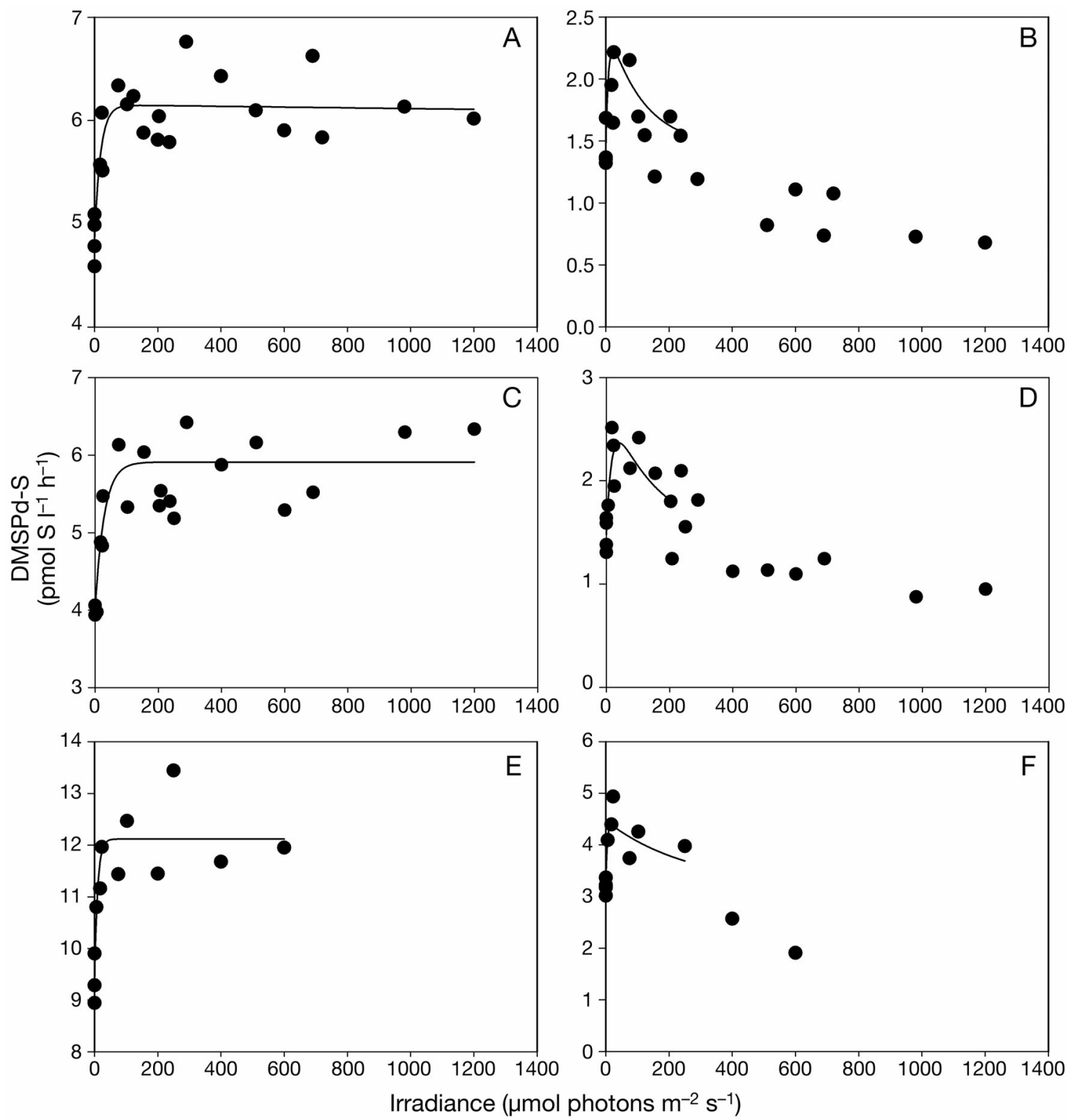

Fig. 4. Assimilation of DMSPd-S as a function of irradiance in seawater at (A,C,E) $25 \mathrm{~m}$ and (B,D,F) $125 \mathrm{~m}$ depth. Samples were collected at (A,B) Stns 3, (C,D) 4 and (E,F) ALOHA. The line depicts the best fit by least squares regression of a model adapted from Platt et al. (1980)

data not shown), as has been previously shown by Church et al. (2004) for seawater collected from Stn ALOHA. For all photosynthetron incubations, DMSPd-S and leucine assimilation rates presented a similar response to irradiance, and these 2 parameters were significantly correlated (Table 3 ). The average molar DMSP-S:leucine assimilation ratios ranged from 0.09 to 0.33 and from 0.15 to 0.22 for SML and BSML samples, respectively.

SML and BSML samples were also incubated with ${ }^{35} \mathrm{~S}$-DMSP for $2 \mathrm{~h}$ under a series of light intensities and then post-light incubated in the dark for an additional $2 \mathrm{~h}$ (Fig. 5). During the post-light incubation (dark) period, SML seawater maintained DMSPd-S and leucine assimilation rates mostly within $\pm 20 \%$ of the light-exposed rate and did not show any clear trend. In contrast, post-light incubated BSML samples had DMSPd-S and leucine assimilation rates that were 20 to $96 \%$ and 21 to $106 \%$ of the light-exposed rates, respectively, with the lowest values in the samples pre-exposed to the highest irradiance. 
Table 2. Photophysiological parameters describing the response of ${ }^{3} \mathrm{H}$-leucine and ${ }^{35} \mathrm{~S}-\mathrm{DMSP}$ assimilation to photosynthetically active radiation light intensity obtained from the best fit by least squares regression of the model adapted from Platt et al. (1980). DMSP: dimethylsulfoniopropionate

\begin{tabular}{|c|c|c|c|c|c|c|c|c|c|c|c|c|c|}
\hline \multirow{3}{*}{$\begin{array}{l}\text { Depth } \\
\text { (m) }\end{array}$} & \multirow{3}{*}{ Stn } & \multirow{3}{*}{\multicolumn{2}{|c|}{$\begin{array}{c}\alpha\left(\mathrm{pM} \mathrm{h}^{-1}[\mu \mathrm{mol}\right. \\
\left.\left.\text { photons m }{ }^{-2} \mathrm{~s}^{-1}\right]^{-1}\right) \\
\text { DMSP-S Leucine }\end{array}$}} & \multirow{2}{*}{\multicolumn{2}{|c|}{$\begin{array}{l}\beta\left(\mathrm{pM} \mathrm{h}^{-1}[\mu \mathrm{mol}\right. \\
\left.\left.\text { photons } \mathrm{m}^{-2} \mathrm{~s}^{-1}\right]^{-1}\right)\end{array}$}} & \multicolumn{4}{|c|}{ Assimilation $\left(\mathrm{pM} \mathrm{h}^{-1}\right)$} & \multirow{2}{*}{\multicolumn{2}{|c|}{$\begin{array}{c}E_{k}(\mu \mathrm{mol} \\
\left.\text { photons } \mathrm{m}^{-2} \mathrm{~s}^{-1}\right)\end{array}$}} & \multicolumn{2}{|c|}{$\mathrm{R}^{2}$} \\
\hline & & & & & & Da & rk & Maxi & mum & & & & \\
\hline & & & & DMSP-S & Leucine & DMSP-S & Leucine & DMSP-S & Leucine & DMSP-S & Leucine & DMSP-S & Leucine \\
\hline \multirow[t]{3}{*}{25} & 3 & 0.07 & 0.10 & $3.7 \mathrm{E}-05$ & $2.2 \mathrm{E}-14$ & 4.86 & 20.65 & 6.15 & 28.89 & 92 & 205 & 0.77 & 0.83 \\
\hline & 4 & 0.07 & 0.19 & $3.9 \mathrm{E}-11$ & $2.3 \mathrm{E}-14$ & 4.00 & 24.28 & 5.91 & 29.87 & 89 & 159 & 0.71 & 0.49 \\
\hline & ALOHA & 0.28 & 0.35 & $2.1 \mathrm{E}-11$ & $1.7 \mathrm{E}-12$ & 9.38 & 29.12 & 12.12 & 39.45 & 43 & 112 & 0.81 & 0.91 \\
\hline \multirow[t]{3}{*}{125} & 3 & 0.11 & 0.89 & $9.2 E-03$ & $2.7 \mathrm{E}-02$ & 1.45 & 13.42 & 2.23 & 24.17 & 20 & 27 & 0.78 & 0.81 \\
\hline & 4 & 0.07 & 0.48 & $9.0 \mathrm{E}-03$ & $1.8 \mathrm{E}-02$ & 1.48 & 9.65 & 2.37 & 13.63 & 34 & 29 & 0.60 & 0.82 \\
\hline & ALOHA & 0.29 & 1.15 & 1.6E-02 & $4.8 \mathrm{E}-03$ & 3.19 & 13.38 & 4.37 & 23.78 & 15 & 21 & 0.80 & 0.94 \\
\hline
\end{tabular}

Table 3. Molar ratio of ${ }^{35} \mathrm{~S}$-DMSP to ${ }^{3} \mathrm{H}$-leucine assimilation (S:Leu) and Pearson correlation coefficients between the 2 variables, for samples collected from 25 and $125 \mathrm{~m}$ and exposed to a gradient of light intensities. All correlations are significant at $\mathrm{p}<0.001$

\begin{tabular}{|lccc|}
\hline Depth $(\mathrm{m})$ & Stn & S:Leu $( \pm \mathrm{SD})$ & $\mathrm{r}(\mathrm{n})$ \\
\hline 25 & 3 & $0.09 \pm 0.01$ & $0.92(20)$ \\
& 4 & $0.18 \pm 0.01$ & $0.85(20)$ \\
& ALOHA & $0.33 \pm 0.02$ & $0.87(11)$ \\
& 3 & $0.22 \pm 0.02$ & $0.73(22)$ \\
& 4 & $0.15 \pm 0.02$ & $0.91(22)$ \\
& ALOHA & $0.21 \pm 0.03$ & $0.89(12)$ \\
\hline
\end{tabular}

\section{Relationship between DMSPd-S assimilation and DMS yield}

DMSPd-S assimilation and DMS yields in samples incubated at different light intensities were inversely correlated in samples from the SML $(\mathrm{r}=-0.88,-0.78$, and $-0.82 ; \mathrm{p}<0.005$; Fig. 6A-C, respectively). A $1 \%$ increase in the assimilation yield resulted in a 2.3 to $3.7 \%$ decrease in the DMS yield.

\section{Production of other metabolic products}

DMSPd was taken up quickly by the microbial community; a percentage of it was gradually assimilated into proteins (up to $7.7 \%$ ) and a percentage remained as untransformed ${ }^{35} \mathrm{~S}-\mathrm{DMSP}$ within the cells $(3.9 \%)$, even $24 \mathrm{~h}$ after the tracer addition to the seawater samples (Fig. 7). An unidentified cellular pool of ${ }^{35} \mathrm{~S}$ also appeared after $12 \mathrm{~h}$ of incubation (3.2\%). DMS and other unidentified volatiles were also formed from ${ }^{35} \mathrm{~S}-\mathrm{DMSPd} .{ }^{35} \mathrm{~S}-\mathrm{DMS}$ accumulated for up to $8 \mathrm{~h}$ and then remained steady (6.0 to $6.7 \%)$. In contrast to DMS, the accumulation of other volatiles (likely methanethiol, Kiene 1996) reached a maximum at $t=$
$4 \mathrm{~h}(9.4 \%)$ and then declined $(3.7 \%, 24 \mathrm{~h})$. Dissolved non-volatile (DNV) sulfur compounds constituted the main product of ${ }^{35} \mathrm{~S}$-DMSP during the whole incubation time, representing 65 and $75 \%$ of the consumed ${ }^{35} \mathrm{~S}-\mathrm{DMSP}$ at $t=1 \mathrm{~h}$ and $t=24 \mathrm{~h}$, respectively.

\section{DISCUSSION}

\section{DMSP cycling and contribution to bacterial $\mathrm{S}$ and $\mathrm{C}$ demand}

Even though the NPSG represents the largest contiguous biome on Earth, there is not, to our knowledge, information on dissolved DMSP (DMSPd) standing pools and dynamics in this system. Only recently, Kiene \& Slezak (2006) showed that traditional sampling procedures can significantly increase the concentration of DMSPd and suggested an approach to minimize this artifact. Even though only a few measurements made using this new method have been published (Kiene \& Slezak 2006, del Valle et al. 2007, Damm et al. 2008), they all report DMSPd concentrations that are much lower than previously observed and normally $<2 \mathrm{nM}$. In the present study, DMSPd concentrations obtained with this approach were low, ranging from 0.3 to $1.1 \mathrm{nM}$ in the SML (Fig. 2). Kiene \& Slezak (2006) also reported that DMSPd presented a strong linear relationship with particulate DMSP (DMSPp, calculated from the difference between DMSPt and DMSPd), with a much lower slope in a productive system than in an oligotrophic system. In the oligotrophic NPSG, the slope for this relation was 0.041, 5-fold lower than in the Sargasso Sea and $\sim 3$ to 4 -fold higher than in the polar productive shelves of the Ross Sea (Kiene \& Slezak 2006) and the Svalbard Archipelago (Damm et al. 2008). The lower ratio in the oligotrophic NPSG compared to the Sargasso Sea, despite the fact that both systems had 


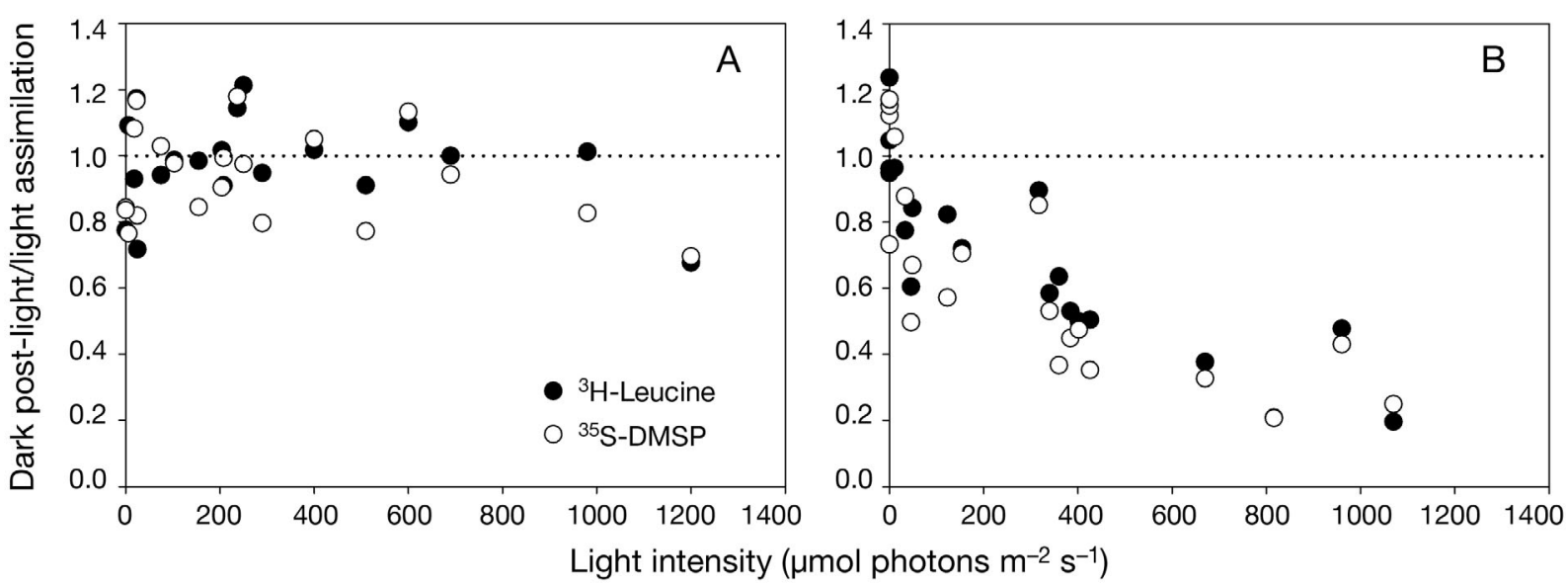

Fig. 5. Ratio of dark post-light ( 2 to $4 \mathrm{~h}$ incubation time) versus light ( 0 to $2 \mathrm{~h}$ incubation time) leucine and DMSPd-S assimilation as a function of incubation light intensity in seawater at (A) $25 \mathrm{~m}$ and (B) $125 \mathrm{~m}$ depth collected at Stn 4. Dotted line denotes the 1:1 ratio. DMSPd: dissolved dimethylsulfoniopropionate

similar DMSPp concentrations (i.e. $<16 \mathrm{nM}$ ), might be partially explained by the more rapid turnover of the DMSPd pool in the NPSG, which can lead to lower DMSPd concentrations. In the NPSG, DMSPd turnover times $(1 / k)$ ranged from 4 to $12 \mathrm{~h}$ (August to October, Fig. 2), while in the Sargasso Sea, turnover times ranged from 14 to $20 \mathrm{~h}$ (July, Gabric et al. 2008). In the NPSG, the contribution of DMSPp-carbon (5 moles of C per mole of DMSP) to particulate organic carbon (POC) averaged 2.5 and $1.5 \%$ for 25 and 125 $\mathrm{m}$ seawater, respectively, during the dates sampled (data not shown), which is within the range of 1 to $5 \%$ normally reported for other oceanic systems (Kiene et al. 2000, Simó et al. 2009). If we assume that all DMSPp is present in live POC, using average, historical Stn ALOHA adenosine triphosphate (ATP) concentrations for the months of August, September, and October as an estimate for the amount of carbon in live cells (using a carbon to ATP ratio of $250 \mathrm{~g} \mathrm{~g}^{-1}$, Karl 1980), we can estimate that DMSPp-carbon constitutes $8 \%$ of the carbon associated with live POC at $25 \mathrm{~m}$ and $3 \%$ at $125 \mathrm{~m}$.

In the NPSG, the consumption of DMSPd satisfied 20 to $67 \%$ and 19 to $41 \%$ of the bacterial sulfur production (BSP) in samples collected at $25 \mathrm{~m}$ and $125 \mathrm{~m}$, respectively, calculated from bacterial production and assuming a bacterial C:S molar ratio of 248 (Cuhel et al. 1982). These values are on the lower end of those reported for other areas using the same C:S ratio (Kiene \& Linn 2000a) or even a lower C:S ratio (Zubkov et al. 2001, Simó et al. 2002). Simó et al. (2009) found that, during an annual study off the NW Mediterranean coast, BSP was positively correlated to DMSPp:chlorophyll a ratios. Because our study took place during late summer and early fall, when DMSPp:chlorophyll a ratios are below the annual average ( $\mathrm{S}$. T. Wilson pers. comm.), it is possible that DMSPd can become a more important source of reduced sulfur to the bacterial community during higher DMSPp:chlorophyll a months (i.e. February to May). The contribution of DMSPd to bacterial carbon demand (BCD) in the surface mixed layer, estimated using a bacterial growth efficiency (BGE) of 0.12 (del Giorgio \& Cole 2000), averaged $4.7 \%$ throughout the water column, with values ranging from 1.2 to $9.5 \%$. These values are within the range observed in other studies (1 to $13 \%$, Kiene et al. 2000; 3 to $30 \%$, Simó et al. $2002 ; 5 \%$, Pinhassi et al. $2005 ; 0.5$ to $6 \%$, Simó et al. 2009) and represent an important fraction of the $\mathrm{BCD}$, considering that DMSPd constitutes only one of many compounds comprising the complex dissolved organic matter pool. It must be noted that several factors can affect the calculation of the BSD and BCD satisfied by DMSPd. One of the main factors is the uncertainty in the different ratios needed to estimate both parameters (i.e. BGE, C:S molar ratio, and the C:leucine assimilation ratio). Another factor that needs to be taken into account is that the calculated amount of assimilated $\mathrm{S}$ and $\mathrm{C}$ depends directly on the measured concentration of DMSPd, which is operationally defined as that passing through a GF/F filter $(0.7 \mu \mathrm{m}$ nominal pore size). Even though the sampling methods employed in this study have been tested to be optimal to reduce release of cellular DMSP and therefore minimize artificially high DMSPd concentrations (Kiene \& Slezak 2006), there is still the question of how much of this DMSPd is actually available to the cells (C. X. Li et al. unpubl.). 

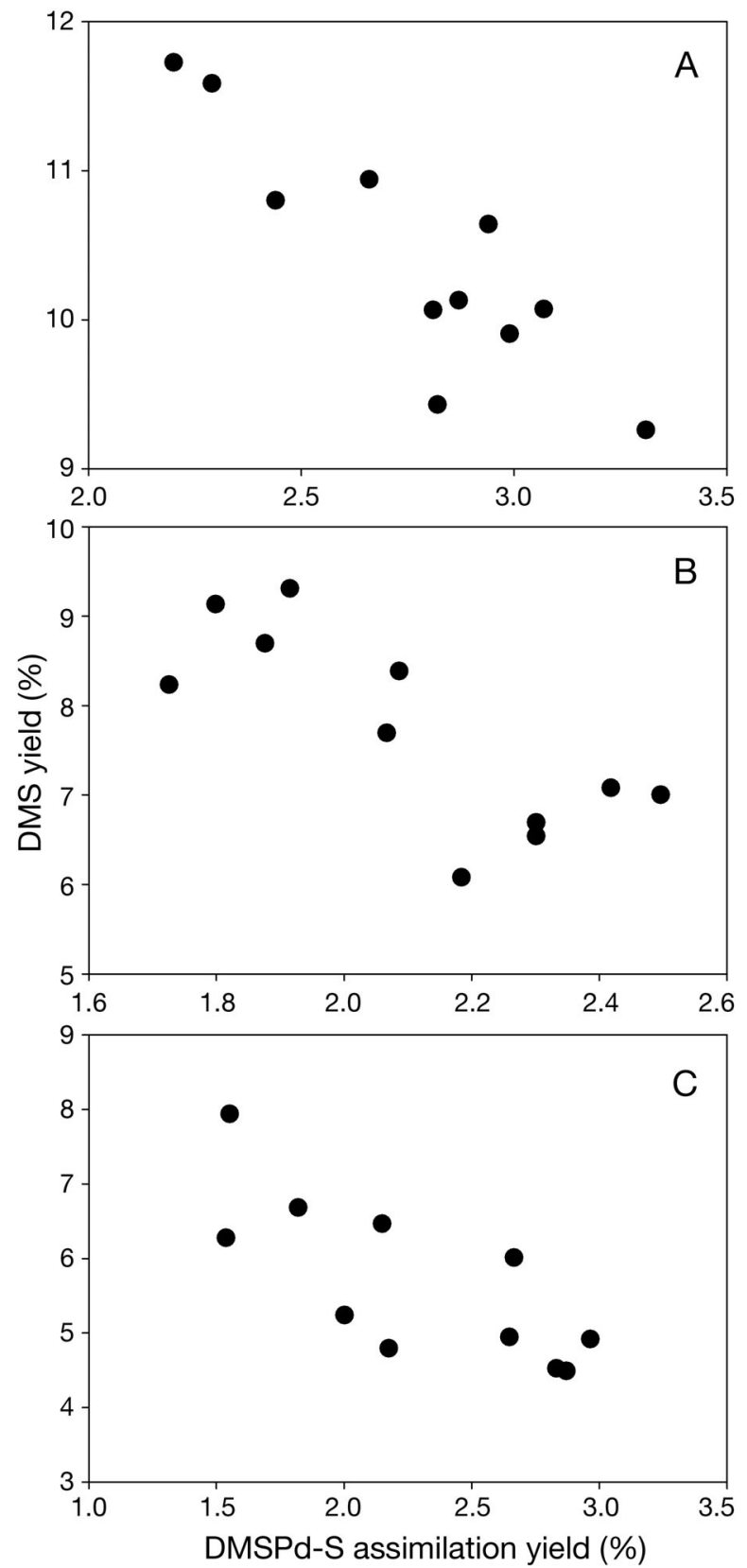

Fig. 6. Dissolved dimethylsulfoniopropionate (DMSPd)-S assimilation versus dimethylsulfide (DMS) yield. Seawater from $25 \mathrm{~m}$ was amended with $200 \mathrm{nM}$ DMDS and ${ }^{35} \mathrm{~S}-\mathrm{DMSP}$ before being incubated under different irradiances $(0$ to $1200 \mu \mathrm{mol}$ photons $\mathrm{m}^{-2} \mathrm{~s}^{-1}$ ). Seawater was collected from (A) Stn 3 and $(B, C)$ Stn ALOHA. Each data point represents a single assimilation yield measurement and the average of duplicate DMS yield measurements

\section{Effect of PAR on DMSPd-S assimilation}

Few studies have previously assessed the effect of PAR on DMSPd assimilation. Vila-Costa et al. (2006)

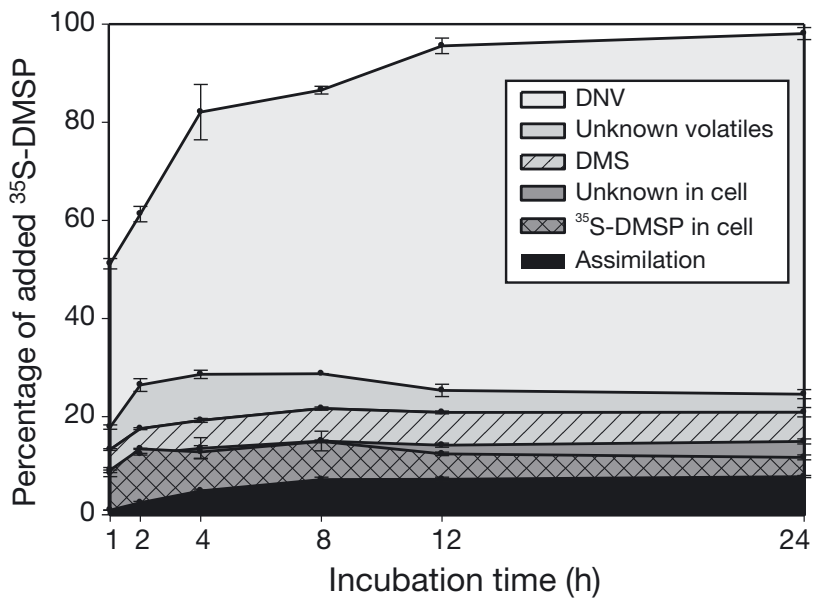

Fig. 7. Time course of ${ }^{35} \mathrm{~S}$-product formation from ${ }^{35} \mathrm{~S}$-DMSP in seawater (25 m depth) collected at Stn 4 . Error bars represent the SE of triplicate measurements. DNV: dissolved nonvolatile sulfur. For other abbreviations, see Fig. 6

reported that PAR exposure stimulated DMSPd-S assimilation by picophototrophs up to 2.2-fold, whereas Slezak et al. (2007) found that PAR exposure inhibited assimilation rates in the $<0.8 \mu \mathrm{m}$ fraction during dark post-light incubations in samples collected from the Gulf of Mexico. Recently, RuizGonzález et al. (2012) reported that under sunlight exposure (both including and excluding the UV fraction of the spectra), DMSPd-S assimilation was inhibited in heterotrophic bacteria but stimulated in Synechococcus in the oligotrophic Mediterranean Sea, pointing to light as a factor that can control competition between heterotrophic and autotrophic organisms. In the NPSG, Synechococcus is more than 2 orders of magnitude less abundant than Prochlorococcus and heterotrophic bacteria (Table 1); therefore, it is not likely to have a significant role in DMSP-S cycling. In contrast, Prochlorococcus could be one of the main candidates to dominate the lightstimulation of DMSPd-S assimilation because it is abundant (Table 1), has the capacity to assimilate DMSPd-S (Vila-Costa et al. 2006), and is responsible for most of the light-stimulated leucine assimilation (Björkman et al. 2010). However, the quantitative role of Prochlorococcus in DMSP cycling is presently unresolved. During a test conducted with seawater from $25 \mathrm{~m}$ depth collected at Stn 5, flow-cytometrically sorted Prochlorococcus cells were responsible for only $<6 \%$ of the total DMSPd-S uptake, and there was no difference in the amount of label taken up per cell by Prochlorococcus in light and dark incubated samples. In this test, heterotrophic bacteria were responsible for most of the dark uptake and also for 
the increase in DMSP-S cellular uptake in the light (2.4-fold) (data not shown). A recent study carried out at Stn ALOHA looked at the monthly abundance and diversity of genes encoding the first step of the $d / d$ pathway (dmdA) both at $25 \mathrm{~m}$ and at the deep chlorophyll maximum ( 100 m). At both depths throughout the year, SAR11 dominated the dmdA pool (based on gene abundance measurements, Varaljay et al. in press.). SAR11 requires exogenous reduced $\mathrm{S}$ to grow (Tripp et al. 2008) and can synthesize proteorhodopsin, possibly to capture light energy (Giovannoni et al. 2005). Consequently, it may be a candidate microorganism to contribute to the light-stimulated DMSPd-S assimilation reported herein, but additional field experiments are required to test this hypothesis. Tripp et al. (2008) estimated that $1.5 \times 10^{5}$ SAR11 cells $\mathrm{ml}^{-1}$ can be produced from $1 \mathrm{nM}$ of DMSP as the sole source of reduced S. Assuming DMSP is the only source of reduced $\mathrm{S}$, a doubling time of $24 \mathrm{~h}$ (Tripp 2007), and an assimilation efficiency of $50 \%$ by this strain (Tripp et al. 2008), we estimate from our results that DMSP could satisfy the $\mathrm{S}$ requirements for $0.3 \times 10^{5}$ to $0.7 \times 10^{5} \mathrm{SAR} 11$ cells $\mathrm{ml}^{-1}$ in the dark and $0.4 \times 10^{5}$ to $0.9 \times 10^{5} \mathrm{SAR} 11$ cells $\mathrm{ml}^{-1}$ at $E_{k}$ (Table 2). These population estimates are at the lower end of the range of SAR11 abundances at Stn ALOHA $\left(0.3 \times 10^{5}\right.$ to $6.3 \times 10^{5} \mathrm{SAR} 11 \mathrm{cells} \mathrm{ml}^{-1}$, estimated from 16S rRNA, Eiler et al. 2009). These calculations suggest that, even if SAR11 were responsible for all DMSP-S assimilation in the NPSG, this group is also using other sources of $\mathrm{S}$ besides DMSP to satisfy its cellular S requirements or growing below the maximum specific growth rate, or both.

The response of DMSPd-S assimilation to light exposure differed within the water column. Samples from the SML were better adapted to higher irradiances than BSML seawater, which was evident from the higher $E_{k}$ and lack of photoinhibition at high irradiances $\left(1200 \mu \mathrm{mol}\right.$ photons $\left.\mathrm{m}^{-2} \mathrm{~s}^{-1}\right)$, for both DMSPd-S and leucine assimilation (Table 2). In contrast, samples from BSML were photoinhibited when exposed to high irradiances and reached the assimilation maxima at lower irradiances. When samples from different depths were incubated at an irradiance equivalent to the one experienced at $\sim 21 \mathrm{~m}$, SML samples were photostimulated, while samples from BSML showed either no response or photoinhibition (Fig. 3), in agreement with the results from photosynthetron experiments (Fig. 4). If samples had been incubated in situ, a continuous trend of photostimulation from surface to deep water might have been observed, as predicted by the similar values of $E_{k}$ in samples from $125 \mathrm{~m}$ and the irradiance at the collection depth. Photoinhibition in BSML samples appeared to be lethal because samples did not recover after dark post-light exposure (Fig. 5). Typically, DMSP consumption and DMS production rates are conducted in dark incubations; however, diverse microbial groups depend partially or exclusively on light-mediated processes to satisfy their metabolic energy requirements (Béjà et al. 2000, Kolber et al. 2000, Yutin et al. 2005). Therefore, the effect of light needs to be considered. Light may provide a metabolic advantage to groups that can stimulate the uptake of molecules that provide alternate sources of $\mathrm{C}, \mathrm{S}$, and energy in an oligotrophic environment. UV light is also part of the solar radiation spectrum and may lead to detrimental effects on bacterioplankton metabolism (Aas et al. 1996, Jeffrey et al. 1996, Sommaruga et al. 1997). Open ocean waters are characterized by rapid attenuation of UV radiation, and even in the clear waters of the NPSG, $90 \%$ of the surface UV-B (280 to $315 \mathrm{~nm}$ ) and UV-A (315 to $400 \mathrm{~nm}$ ) radiation have already been absorbed at $18 \mathrm{~m}$ and $32 \mathrm{~m}$, respectively (R. M. Letelier pers. comm.). In the NPSG, the mixed layer extends to $58.9 \pm 24.5$ (SD) $\mathrm{m}$ throughout the year, probably ameliorating inhibitory effects of UV radiation. In oligotrophic waters of the Gulf of Mexico, no net accumulation of DNA photodamage was observed in moderate seas under climatic conditions that are normally encountered in the high energy NPSG (wind speeds > 15 knots), indicating that mixing contributes to the movement of damaged organisms to deeper depths where photorepair can occur (Jeffrey et al. 1996). The response of DMSP metabolism to UV radiation under natural irradiance conditions remains to be elucidated (Slezak et al. 2007).

\section{Relationship between leucine and DMSP-S assimilation}

In the NPSG, leucine assimilation has been shown to be consistently photostimulated throughout the year, responding to irradiance following a photosynthesis-like pattern (Church et al. 2006). Because leucine assimilation is usually used as an estimate for protein biosynthesis (Kirchman et al. 1985), and DMSPd-S is used in the synthesis of methionine, which in turn is also used for protein biosynthesis (Kiene et al. 1999), one may expect to see a similar pattern between the assimilation of DMSPd-S and the assimilation of leucine. A significant correlation between these 2 variables was observed during the development of an Fe-induced bloom (dominated by 
autotrophic nanoflagellates, Lizotte et al. 2009) and during an annual time series (Simó et al. 2009). In these studies, the correlation between DMSPd-S and leucine assimilation was observed during a succession of bacterial assemblages. In contrast, in our study, this correlation was driven by rapid changes in physical conditions (i.e. light exposure) for a given microbial assemblage. This close relation between these metabolic processes suggests that the microbial community is able to regulate the assimilation of DMSPd-S to satisfy the increased $\mathrm{S}$ demand for protein synthesis.

The observed coupling between leucine and DMSPd-S assimilation suggests, but does not prove, that the same microbial group or groups are responsible for both processes. In the coastal Mediterranean Sea, whole-community DMSPd-S and leucine assimilation were correlated during an annual study (Simó et al. 2009); however, when the assimilation of these 2 compounds was analyzed for individual bacterial groups, no clear relationship was found (Vila-Costa et al. 2007). In a transect across the North Atlantic, Michelou et al. (2007) showed that Prochlorococcus can be responsible for a significant fraction of the light-stimulated leucine uptake when it is abundant, but other photoheterotrophic organisms (e.g. proteorhodopsin-bearing and aerobic anoxygenic bacteria) might also play a role. In contrast, in the NPSG, Prochlorococcus appears to drive most, if not all, of the light-stimulated leucine assimilation, with low nucleic acid content bacteria (e.g. SAR11) presenting neither a negative nor a positive response to light exposure (Björkman et al. 2010), which is in contrast to our test results for cell-sorted ${ }^{35} \mathrm{~S}$-DMSP assimilation (see section 'Effect of PAR on DMSPd-S assimilation'). Other studies have reported both photostimulation (Straza \& Kirchman 2011) and photoinhibition (Alonso-Sáez et al. 2006) of leucine assimilation under PAR by SAR11, suggesting that leucine assimilation by this group might be highly influenced by the physical, chemical, and nutritional characteristics of the system. These results might indicate a tight link between photosynthetic production and release of dissolved organic matter by Prochlorococcus and growth of SAR11. Church et al. (2004) reported similarities between leucine and bicarbonate uptake responses to PAR in whole-community incubations at Stn ALOHA, suggesting that an upregulation of photoheterotrophic metabolism jointly takes place with autotrophic supported growth. Because Prochlorococcus is the most abundant phototroph (Campbell \& Vaulot 1993) and is also responsible for photostimulated uptake of leucine (Björkman et al. 2010), it is possible that its growth and consequent exudation of the produced photosynthate (9 to $24 \%$ in cultures, Bertilsson et al. 2005) might stimulate the cellular growth of SAR11 and therefore stimulate their S requirement. Understanding the complex synergistic interactions among the different microbial groups in a given system continues to be a challenge.

\section{DMS production versus demethylation/ demethiolation $(d / d)$ pathway}

DMSPd can undergo at least 2 different metabolic transformation pathways, one yielding DMS and one yielding methanethiol (d/d pathway) (Todd et al. 2007, Todd et al. 2009, Howard et al. 2011). Current understanding is that DMS production is a 'leftover' from DMSP metabolism, meaning that the portion of DMSPd that is not transformed into methanethiol for protein synthesis then is available for DMS production. Consequently, this metabolic flexibility ultimately controls the amount of DMS that can be produced, which also constrains the seato-air DMS flux. The selection of each pathway is thought to be controlled by the $\mathrm{S}$ requirements of the cell (Kiene \& Linn 2000b) or the availability of DMSPd or other S-containing substrates to meet the $\mathrm{S}$ demand for protein synthesis (Pinhassi et al. 2005), or both. In our study, the increase in the assimilation of DMSP-S due to light exposure was inversely coupled to DMS production yield from DMSPd in surface waters (Fig. 6), suggesting that an increase in assimilation actually decreases the amount of S available for DMS production, as predicted by the current competing metabolic pathways model. Over the development of an Feinduced bloom, DMSPd-S assimilation yield and DMS yield were also found to be negatively correlated (Lizotte et al. 2009). In our study, similar changes occurred in a single community in response to light manipulations. It is not possible, however, to know if the same organisms are responsible for upregulating assimilation while down-regulating DMS production or if our observations result from more complex interspecies relationships. Although it is true that the $\mathrm{S}$ that is assimilated is no longer available for direct conversion into DMS (at least in the short term), in oceanic systems, normally less than $\sim 20 \%$ of the DMSP-d S is assimilated, and 4 to $14 \%$ of the DMSPd-S is found as DMS (Kiene \& Linn 2000b, Royer et al. 2010), leaving 66 to $76 \%$ of the sulfur following a different fate (Fig. 7). An important fraction of this $\mathrm{S}$ is completely oxidized to sul- 
fate (Kiene \& Linn 2000b), indicating that the produced methanethiol is being used as a source of energy and/or as a methylating compound. It is a possibility that these other metabolic fates of the methanethiol produced also contribute to the control of the balance between DMS and methanethiol production, for example, during periods of cellular energy limitation when oxidation may be favored. If assimilation of the DMSP-S into proteins is the final goal of the $d / d$ pathway, then this process is highly inefficient, because in the NPSG, only $8 \%$ of the DMSP that underwent the $d / d$ pathway was found in proteins (Fig. 7).

Vila-Costa et al. (2010) observed that, after addition of DMSP, genes involved in the degradation of 3-carbon (3C) compounds were overrepresented in the microbial community transcriptome compared to controls receiving no DMSP. The other product from both DMS and methanethiol production from DMSP is a 3C compound, which therefore seems to be quickly utilized by the bacterial community. This study points to the importance of DMSP as a C source, a factor that is not normally considered as a potential control between the d/d and DMS production pathways. The production of methanethiol is probably a more efficient pathway in terms of $\mathrm{C}$ acquisition from DMSP for the cell because all 5 carbons have the potential to be rapidly used, while DMS has a much slower turnover and is most likely not utilized by the same cell that produced it, resulting in release into the environment of 2 methyl carbons and reduced sulfur (Kiene et al. 2000). The metabolic fate of DMSPd-S might be influenced not only by the direct use of the $\mathrm{S}$ but also by the need for $\mathrm{C}$ or energy. The rapid turnover of DMSPd, together with the fact that cells can accumulate untransformed DMSP, indicates that DMSP is a valuable resource as a supply of $\mathrm{C}$, $\mathrm{S}$, energy, or all 3 of these resources. Our observations of the light stimulation of DMSP-S assimilation advance our understanding of the role that photoheterotrophy can have in biogeochemical cycles and support the recommendation for the consideration of phototrophic microbial processes for a better comprehension of the oceanic $\mathrm{S}$ cycle.

Acknowledgements. We thank the captain and crew of the RV 'Kilo Moana', the HOT team, and the chief scientists M. Church and S. Curless. We also thank K. Doggett and S. Duhamel for flow cytometry analysis, L. Oswald for DMSP analysis, and L. Guidi for statistical analysis. This work was supported by the Gordon and Betty Moore Foundation (Marine Microbiology Initiative Award to D.M.K.) and the National Science Foundation (EF-0424599 to D.M.K. and OCE-0928968 to R.P.K.).

\section{LITERATURE CITED}

Aas P, Lyons MM, Pledger R, Mitchell DL, Jeffrey WH (1996) Inhibition of bacterial activities by solar radiation in nearshore waters and the Gulf of Mexico. Aquat Microb Ecol 11:229-238

Alonso-Sáez L, Gasol JM, Lefort T, Hoefer J, Sommaruga R (2006) Effect of natural sunlight on bacterial activity and differential sensitivity of natural bacterioplankton groups in Northwestern Mediterranean coastal waters. Appl Environ Microbiol 72:5806-5813

Béjà O, Aravind L, Koonin E, Suzuki M and others (2000) Bacterial rhodopsin: evidence for a new type of phototrophy in the sea. Science 289:1902-1906

Bertilsson S, Berglund O, Pullin M, Chisholm S (2005) Release of dissolved organic matter by Prochlorococcus. Vie Milieu 55:225-231

Björkman K, Church MJ, Doggett JK, Karl DM (2010) The effect of light on phosphorus and amino acid uptake in Prochlorococcus spp. in the North Pacific Subtropical Gyre using cell-sorting flow cytometry. Eos Trans AGU 91(26), Ocean Sci Meet Suppl, Abstract BO116-03

> Campbell L, Vaulot D (1993) Photosynthetic picoplankton community structure in the subtropical North Pacific Ocean near Hawaii (station ALOHA). Deep-Sea Res I 40: 2043-2060

Charlson RJ, Lovelock JE, Andreae MO, Warren SG (1987) Oceanic phytoplankton, atmospheric sulfur, cloud albedo and climate. Nature 326:655-661

> Church MJ, Ducklow HW, Karl DM (2004) Light dependence of $\left[{ }^{3} \mathrm{H}\right]$ leucine incorporation in the oligotrophic North Pacific Ocean. Appl Environ Microbiol 70: 4079-4087

Church MJ, Ducklow HW, Letelier RM, Karl DM (2006) Temporal and vertical dynamics in picoplankton photoheterotrophic production in the subtropical North Pacific Ocean. Aquat Microb Ecol 45:41-53

> Cuhel RL, Taylor CD, Jannasch HW (1982) Assimilatory sulfur metabolism in marine microorganisms: considerations for the application of sulfate incorporation into protein as a measurement of natural population protein synthesis. Appl Environ Microbiol 43:160-168

> Damm E, Kiene RP, Schwarz J, Falck E, Dieckmann G (2008) Methane cycling in Arctic shelf water and its relationship with phytoplankton biomass and DMSP. Mar Chem 109: 45-59

del Giorgio PA, Cole J (2000) Bacterial energetics and growth efficiency. In: Kirchman DL (ed) Microbial ecology of the oceans. Wiley, New York, NY, p 289-325

del Valle DA, Kieber DJ, Bisgrove J, Kiene RP (2007) Lightstimulated production of dissolved DMSO by a particleassociated process in the Ross Sea, Antarctica. Limnol Oceanogr 52:2456-2466

Eiler A, Hayakawa DH, Church MJ, Karl DM, Rappé MS (2009) Dynamics of the SAR11 bacterioplankton lineage in relation to environmental conditions in the oligotrophic North Pacific subtropical gyre. Environ Microbiol 11:2291-2300

Ellman GL (1985) A colorimetric method for determining low concentrations of mercaptans. Arch Biochem Biophys 74:443-450

Gabric AJ, Matrai PA, Kiene RK, Cropp R and others (2008) Factors determining the vertical profile of dimethylsulfide in the Sargasso Sea during the summer. DeepSea Res II 55:1505-1518 
Giovannoni SJ, Bibbs L, Cho JC, Stapels MD and others (2005) Proteorhodopsin in the ubiquitous marine bacterium SAR11. Nature 438:82-85

Howard EC, Sun S, Reisch CR, del Valle DA, Burgmann H, Kiene RK, Moran MA (2011) Changes in dimethylsulfoniopropionate demethylase gene assemblages in response to an induced phytoplankton bloom. Appl Environ Microbiol 77:524-531

> Jeffrey WH, Pledger RJ, Aas P, Hager S, Coffin RB, Von Haven R, Mitchell DL (1996) Diel and depth profiles of DNA photodamage in bacterioplankton exposed to ambient solar ultraviolet radiation. Mar Ecol Prog Ser 137:283-291

Karl DM (1980) Cellular nucleotide measurements and applications in microbial ecology. Microbiol Rev 44: 739-796

Karl DM, Lukas R (1996) The Hawaii Ocean Time-series (HOT) program: background, rationale and field implementation. Deep-Sea Res II 43:129-156

Keller MD, Bellows WK, Guillard RRL (1989) Dimethyl sulfide production in marine phytoplankton. In: Saltzman E, Cooper WJ (eds) Biogenic sulfur in the environment. Am Chem Soc, New York, NY, p 167-182

Kiene RP (1996) Production of methanethiol from dimethylsulfoniopropionate in marine surface waters. Mar Chem 54:69-83

Kiene RP, Linn LJ (2000a) Distribution and turnover of dissolved DMSP and its relationship with bacterial production in the Gulf of Mexico. Limnol Oceanogr 45:849-861

Kiene RP, Linn LJ (2000b) The fate of dissolved dimethylsulfoniopropionate (DMSP) in seawater: tracer studies using ${ }^{35}$ S-DMSP. Geochim Cosmochim Acta 64:2797-2810

$>$ Kiene RP, Service SK (1991) Decomposition of dissolved DMSP and DMS in estuarine waters: dependence on temperature and substrate concentration. Mar Ecol Prog Ser 76:1-11

Kiene RP, Slezak D (2006) Low dissolved DMSP concentrations in seawater revealed by small volume gravity filtration and dialysis sampling. Limnol Oceanogr Methods 4: 80-95

> Kiene RP, Linn LJ, González J, Moran MA, Bruton JA (1999) Dimethylsulfoniopropionate and methanethiol are important precursors of methionine and protein-sulfur in marine bacterioplankton. Appl Environ Microbiol 65: 4549-4558

> Kiene RP, Linn LJ, Bruton JA (2000) New and important roles for DMSP in marine microbial communities. J Sea Res 43:209-224

Kirchman DL, K'nees E, Hodson R (1985) Leucine incorporation and its potential as a measure of protein synthesis by bacteria in natural aquatic systems. Appl Environ Microbiol 49:599-607

Kolber Z, Van Dover C, Niederman R, Falkowski P (2000) Bacterial photosynthesis in surface waters of the open ocean. Nature 407:177-179

> Lewis MR, Smith JC (1983) A small volume, short-incubation-time method for measurement of photosynthesis as a function of incident irradiance. Mar Ecol Prog Ser 13: 99-102

> Lizotte M, Levasseur M, Kudo I, Suzuki K, Tsuda A, Kiene RK, Scarratt MG (2009) Iron-induced alterations of bacterial DMSP metabolism in the western subarctic Pacific during SEEDS-II. Deep-Sea Res II 56:2889-2898

Malmstrom RR, Kiene RP, Kirchman DL (2004) Identification and enumeration of bacteria assimilating dimethylsulf- oniopropionate (DMSP) in the North Atlantic and Gulf of Mexico. Limnol Oceanogr 49:597-606

> Marie D, Partensky F, Jacquet S, Vaulot D (1997) Enumeration and cell cycle analysis of natural populations of marine picoplankton by flow cytometry using the nucleic acid stain SYBR Green I. Appl Environ Microbiol 63: 186-193

> Mary I, Tarran G, Warwick P, Terry M, Scanlan D, Burkill P, Zubkov M (2008) Light enhanced amino acid uptake by dominant bacterioplankton groups in surface waters of the Atlantic Ocean. FEMS Microbiol Ecol 63:36-45

- Michelou VK, Cottrell MT, Kirchman DL (2007) Lightstimulated bacterial production and amino acid assimilation by cyanobacteria and other microbes in the North Atlantic Ocean. Appl Environ Microbiol 73: 5539-5546

Pinhassi J, Simó R, González JM, Vila M and others (2005) Dimethylsulfoniopropionate turnover is linked to the composition and dynamics of the bacterioplankton assemblage during a microcosm phytoplankton bloom. Appl Environ Microbiol 71:7650-7660

Platt T, Gallegos C, Harrison W (1980) Photoinhibition of photosynthesis in natural assemblages of marine phytoplankton. J Mar Res 38:687-701

Royer SJ, Levasseur M, Lizotte M, Arychuk M and others (2010) Microbial dimethylsulfoniopropionate (DMSP) dynamics along a natural iron gradient in the northeast subarctic Pacific. Limnol Oceanogr 55:1614-1626

- Ruiz-González C, Simó R, Vila-Costa M, Sommaruga R, Gasol JM (2012) Sunlight modulates the relative importance of heterotrophic bacteria and picophytoplankton in DMSP-sulphur uptake. ISME J 6:650-659

Shaw GE (1983) Bio-controlled thermostasis involving the sulfur cycle. Clim Change 5:297-303

Simó R, Vila-Costa M, Alonso-Sáez L, Cardelús C, Guadayol Ò, Vázquez-Domínguez E, Gasol JM (2009) Annual DMSP contribution to $\mathrm{S}$ and $\mathrm{C}$ fluxes through phytoplankton and bacterioplankton in a NW Mediterranean coastal site. Aquat Microb Ecol 57:43-55

> Simó R, Archer SD, Pedrós-Alió C, Gilpin L, Stelfox-Widdicombe CE (2002) Coupled dynamics of dimethylsulfoniopropionate and dimethylsulfide cycling and the microbial food web in surface waters of the North Atlantic. Limnol Oceanogr 47:53-61

> Slezak D, Kiene RP, Toole DA, Simó R, Kieber DJ (2007) Effects of solar radiation on the fate of dissolved DMSP and conversion to DMS in seawater. Aquat Sci 69: 377-393

Sommaruga R, Obernosterer I, Herndl GJ, Psenner R (1997) Inhibitory effect of solar radiation on thymidine and leucine incorporation by freshwater and marine bacterioplankton. Appl Environ Microbiol 63:4178-4184

Steinke M, Daniel C, Kirst GO (1996) DMSP lyase in marine macro- and microalgae: interspecific differences in cleavage activity. In: Kiene RK, Visscher PT, Keller MD, Kirst GO (eds) Biological and environmental chemistry of DMSP and related sulfonium compounds. Plenum, New York, NY, p 317-324

Straza TRA, Kirchman DL (2011) Single-cell response of bacterial groups to light and other environmental factors in the Delaware Bay, USA. Aquat Microb Ecol 62: 267-277

> Todd JD, Rogers R, Guo Li Y, Wexler M and others (2007) Structural and regulatory genes required to make the gas dimethyl sulfide in bacteria. Science 315:666-669 
Todd JD, Curson ARJ, Dupont CL, Nicholson P, Johnston AWB (2009) The dddP gene, encoding a novel enzyme that converts dimethylsulfoniopropionate into dimethyl sulfide, is widespread in ocean and metagenomes and marine bacteria and also occurs in some Ascomycete fungi. Environ Microbiol 11:1624-1625

Tripp HJ (2007) Genomic-assisted determination of the natural nutrient requirements of the cosmopolitan marine bacterium 'Candidatus Pelagibacter ubique'. PhD dissertation, Oregon State University, Corvallis, OR

Tripp HJ, Kitner JB, Schwalbach MS, Dacey JW, Wilhelm LJ, Giovannoni SJ (2008) SAR11 marine bacteria require exogenous reduced sulphur for growth. Nature 452: 741-744

Varaljay VA, Gifford SM, Wilson ST, Sharma S, Karl DM, Moran MA (in press) Bacterial dimethylsulfoniopropionate-degrading genes in the oligotrophic North Pacific Subtropical Gyre. Appl Environ Microbiol

Vila M, Simó R, Kiene RP, Pinhassi J, Gonzalez JM, Moran MA, Pedros-Alio C (2004) Use of microautoradiography combined with fluorescence in situ hybridization to determine dimethylsulfoniopropionate incorporation by marine bacterioplankton taxa. Appl Environ Microbiol 70:4648-4657

- Vila-Costa M, Simó R, Harada H, Gasol JM, Slezak D, Kiene

Editorial responsibility: Ruben Sommaruga, Innsbruck, Austria
RP (2006) Dimethylsulfoniopropionate uptake by marine phytoplankton. Science 314:652-654

Vila-Costa M, Pinhassi J, Alonso C, Pernthaler J, Simó R (2007) An annual cycle of dimethylsulfoniopropionatesulfur and leucine assimilating bacterioplankton in the coastal NW Mediterranean. Environ Microbiol 9: 2451-2463

Vila-Costa M, Rinta-Kanto JM, Sun S, Sharma S, Poretsky R, Moran MA (2010) Transcriptomic analysis of a marine bacterial community enriched with dimethylsulfoniopropionate. ISME J 4:1410-1420

> Wolfe GV, Kiene RP (1993) Radioisotope and chemical inhibitor measurements of dimethyl sulfide consumption rates and kinetics in estuarine waters. Mar Ecol Prog Ser 99:261-269

Yutin N, Suzuki MT, Béjà O (2005) Novel primers reveal wider diversity among marine aerobic anoxygenic phototrophs. Appl Environ Microbiol 71:8958-8962

Zubkov MV (2009) Photoheterotrophy in marine prokaryotes. J Plankton Res 31:933-938

Zubkov MV, Fuchs BM, Archer SD, Kiene RP, Amann R, Burkill PH (2001) Linking the composition of bacterioplankton to rapid turnover of dissolved dimethylsulphoniopropionate in an algal bloom in the North Sea. Environ Microbiol 3:304-311

Submitted: October 6, 2011; Accepted: January 23, 2012

Proofs received from author(s): March 7, 2012 